\title{
Concentrations of Selected Heavy Metals in Bones and Femoral Bone Structure of Bank (Myodes glareolus) and Common (Microtus arvalis) Voles from Different Polluted Biotopes in Slovakia
}

\author{
M. Martiniaková $\cdot$ R. Omelka • A. Jančová • \\ R. Stawarz • G. Formicki
}

Received: 12 March 2010/ Accepted: 4 May 2010/Published online: 9 June 2010

(c) The Author(s) 2010. This article is published with open access at Springerlink.com

\begin{abstract}
Concentrations of selected heavy metals in the femora and femoral bone structure of bank (Myodes glareolus) and common (Microtus arvalis) voles from different polluted biotopes in Slovakia (Kolíňany and Nováky sites) were investigated. Length, weight, and histological structure of vole bones were also analyzed. We observed higher concentrations of lead $(\mathrm{Pb})$, iron $(\mathrm{Fe})$, copper $(\mathrm{Cu})$, and zinc $(\mathrm{Zn})$ in the bones of both species from the Kolíñany site. Significant differences were observed in the concentration of $\mathrm{Fe}$ in bank and common voles $(p<0.05)$ and in the concentration of $\mathrm{Zn}(p<0.05)$ in common voles. The animals from Nováky had higher concentrations of cadmium $(\mathrm{Cd})$ and nickel $(\mathrm{Ni})$ in their bones; however, the differences were not significant. The measured values for bone length and weight were higher in both species from Nováky $(p<0.05)$. We did not identify differences in qualitative histological characteristics of the femora between the voles (M. glareolus and M. arvalis separately) between the two biotopes. In addition, no statistically significant differences for any the measured variables of primary osteons' vascular canals were observed. Correlation analysis in M. glareolus showed a strong positive relation between $\mathrm{Cd}$ and $\mathrm{Ni}(r=0.52) \mathrm{Pb}$
\end{abstract}

M. Martiniaková $(\bowtie) \cdot$ A. Jančová

Department of Zoology and Anthropology, Constantine the Philosopher University, 94974 Nitra, Slovak Republic

e-mail: mmartiniakova@ukf.sk

R. Omelka

Department of Botany and Genetics, Constantine the Philosopher University, 94974 Nitra, Slovak Republic

R. Stawarz - G. Formicki

Institute of Biology, Krakow Pedagogical University,

31054 Krakow, Poland and bone weight ( $r=0.53), \mathrm{Fe}$ and bone weight $(r=0.52)$, and $\mathrm{Fe}$ and perimeter size of primary osteons' vascular canals $(r=0.55)$. In common voles, a strong positive relation was found between $\mathrm{Fe}$ and $\mathrm{Cu}(r=0.60)$ and between $\mathrm{Fe}$ and perimeter size of vascular canals of primary osteons $(r=0.55)$. Our results indicate that accumulation of some heavy metals is slightly increased in the femora of both species at Kolíñany.

Many investigations have been performed to determine heavy-metal contamination in various species of mammals. Field studies have shown that high levels of various heavy metals in the environment may appropriately be monitored by the assessment of their concentrations in target organs of free-living small mammals (mainly rodents). The increased levels have usually been considered to relate to environmental pollution, and significant relations have been found between residues of metals in soil and those in body organs or tissues (Shore 1995; Ieradi et al. 2003).

The pattern of heavy-metal distribution and levels of heavy metals in various tissues of rodents are similar to those found in humans. Therefore, in research rodents frequently serve as mammalian surrogates for humans (Shore and Rattner 2001). The bank vole (Clethrionomys [= Myodes glareolus $]$ ) is a small microtine rodent that is ubiquitous throughout Europe and one of the most common woodland rodents in Slovakia. Seeds, fruits, and green vegetation constitute approximately $44 \%$ of its food, whereas insects, earthworms and other invertebrates contribute between 9 and 23\% depending on the season. In winter, bank voles add tree bark to their food supply (Zemanek 1972; Gdula-Argasinska et al. 2004). This species has been used to monitor environmental pollution from a variety of technogenic sources (Milton and Johnson 1999; 
Milton et al. 2003; Topolska et al. 2004). The common vole (Microtus arvalis) is the species that has drawn the attention of cytogeneticists for many years, and currently it is one of the most karyologically studied free-living mammals in Europe (Topashka-Ancheva et al. 2003; Moska et al. 2004; Gileva et al. 2005). These voles feed mainly on leaves, stems, and roots of grasses and other plants and seem to preferentially feed on plants with high nitrogen content (Macdonald and Tattersall 2001).

During development, calcified tissues incorporate heavy metals to which they are exposed (Gdula-Argasinska et al. 2004). Bone tissue has some advantages compared with soft tissues, such as liver and kidney, because once incorporated into bone, the metals are subject to bone turnover (remodeling proceeds at approximately $10 \% / y$ in adult individuals). Therefore, an accurate historic record of exposure to various elements is retained in the bone, and, consequently, bone tissue would appear to be a suitable long-term bioindicator of environmental exposure.

Among heavy metals, cadmium $(\mathrm{Cd})$ and lead $(\mathrm{Pb}$; nonessential and xenobiotic) often cause acute and chronic environmental contamination. $\mathrm{Cd}$ causes damage primarily to kidney, bone, and lung. It also alters calcium (Ca) metabolism, leading to osteomalacia (Kido et al. 1993). $\mathrm{Pb}$ accumulates mainly in bone, but the critical organs for $\mathrm{Pb}$ intoxication are nervous system, kidney, and bone marrow (Friberg et al. 1986). These nonessential metals are toxic to humans and other animals, even in very low concentrations (Haider et al. 2004). In contrast, copper $(\mathrm{Cu})$, iron $(\mathrm{Fe})$, nickel $(\mathrm{Ni})$, and zinc $(\mathrm{Zn})$ are essential for the correct functioning of living organisms. However, essential metals can also produce toxic effects when the metals intake in high concentrations (Angelova et al. 2004). For example, $\mathrm{Fe}$ is essential for the formation of hemoglobin, myoglobin, and many enzymes; it is also involved in the formation of red blood cells and helps fight stress and disease (Leung et al. 1999). In contrast, an excess of Fe causes vomiting, diarrhea, and damage to the intestines in humans (Haider et al. 2004). Deficiency of essential metals can also negatively affect living organisms. A diet that is deficient in a particular essential element can enhance the accumulation and toxicity of some toxic metals. $\mathrm{Ca}, \mathrm{Fe}$, and $\mathrm{Zn}$ deficiency, for instance, enhance susceptibility to $\mathrm{Cd}$ and $\mathrm{Pb}$ toxicity. It has also been demonstrated that toxic metals can disrupt essential-element metabolism. Cd toxicity affects $\mathrm{Ca}$ metabolism either by direct toxicity to bone or indirectly through renal toxicity (Goyer 1997).

Only a few studies have been focused on the distribution of heavy metals in selected organs of bank voles. They have concentrated on the accumulation of selected toxic elements in kidney, liver, testes, uterus, and teeth (Appleton et al. 2000; Metcheva et al. 2001; Topolska et al. 2004; Gdula-Argasinska et al. 2004; Wijnhoven et al. 2008). The distribution of selected heavy metals in bones is only rarely found in the literature (Milton and Johnson 1999; Milton et al. 2003).

In general, two types of bone can be identified in rodents: compact bone and spongy bone. Compact bone forms the shafts of long bones, the surfaces of their extremities, short bones, and the outer and inner layers (lamina externa and interna) of the skull vault. Basic constituents of the bones' structural organization are primary and secondary osteons. Primary osteons are not surrounded by a reversal (cement) line, and lamellae around them merge smoothly with the surrounding bone; secondary osteons consist of a central (Haversian) canal, which is surrounded by concentric rings (lamellae) of matrix (Currey 2002; Martiniaková et al. 2007). Spongy bone constitutes the internal part of the long bone extremities (epiphyses) and the middle layer (diploe) of the skull vault in rodents. The bone consists of irregular, sinuous convolutions of lamellae, which create a system of trabeculae and griddles arranged in the direction of biomechanical stress (Rho et al. 1998).

Our study was carried out to contribute to a better evaluation of environmental contamination in two different biotopes in Slovakia. Because bone can serve as a good biomarker of long-term metal accumulation, we analyzed concentrations of selected heavy metals in the femora of two rodent species. Rodents are ideal for monitoring environmental pollution as well as for evaluating the exposure risk for people living in contaminated areas. Therefore, the aim of this study was to analyze concentrations of selected heavy metals $(\mathrm{Pb}, \mathrm{Cd}, \mathrm{Fe}, \mathrm{Ni}, \mathrm{Cu}$, and $\mathrm{Zn}$ ) in the femora of M. glareolus and M. arvalis trapped at different biotopes of a low hill level in Slovakia (Kolíñany and Nováky). Bone length, bone weight, and histological structure of vole bones were also investigated. Finally, the relations of detected metal concentrations and bone structure were determined.

\section{Materials and Methods}

Individuals of bank (M. glareolus, $n=24$ ) and (M. arvalis, $n=15$ ) common voles were obtained by means of standard teriological methods and procedures from wood ecosystems (Jančová et al. 2006) in early spring 2007. The voles were trapped near the coal power station in Nováky (Prievidza district, Slovakia), which is considered to be a strongly polluted region (sources of possible environmental contamination include Nováky chemical plant, coal power station in Nováky, and Handlová-Cígel mines) and near the water pond in Kolíñany (Nitra district, Slovakia), which is located approximately $100 \mathrm{~km}$ from the town of Nováky and is considered to be a relatively polluted region (sources 
Fig. 1 Map of investigated biotopes in the Slovak Republic (Central Europe)

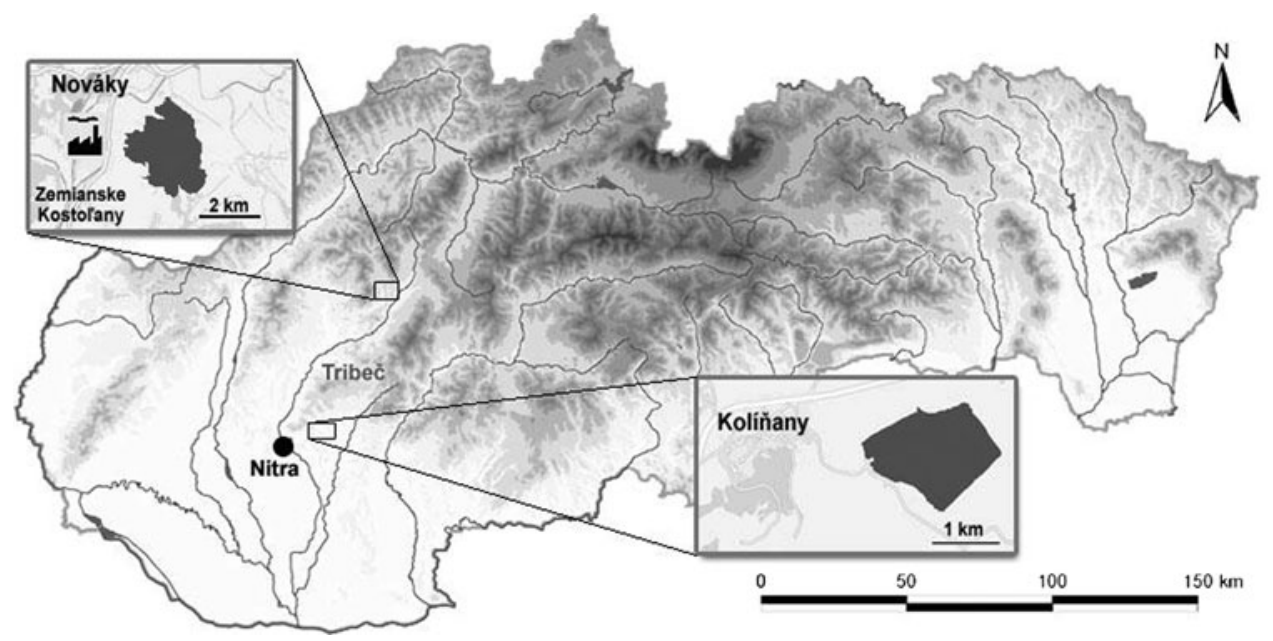

of possible environmental contamination include Calmit Žirany stone pit and limestone pit, aluminium production at Žiar nad Hronom, factories near the Nitra region, and intensive agricultural production). The coal power station is located west of Nováky, and the wind blows predominantly northwest and west. These two biotopes are separated by the Tribeč mountains (Fig. 1). All animals (males) used in the experiment were adult (4 months old), in good physical condition, and without anatomic pathologic conditions. We compared 14 bank voles from Kolínany with 10 from Nováky and 8 common voles from Kolínany with 7 from Nováky. Our research was focused on 78 femora taken from the adult voles. We compared bone length, bone weight, and histological structure of the femora between the animals from different types of environment. Values for macroscopical analysis were expressed as mean \pm SD. Unpaired Student $t$ test was used to distinguish possible differences in bone length and bone weight between examined small mammals.

The concentrations of selected heavy metals $(\mathrm{Pb}, \mathrm{Cd}, \mathrm{Ni}$, $\mathrm{Fe}, \mathrm{Cu}$, and $\mathrm{Zn}$ ) were determined in left femora of investigated mammals $(n=39)$ with the method of atomic absorption spectrophotometry (Perkin Elmer $4100 \mathrm{ZL}$ ) in a graphite furnace (Stawarz et al. 2003). The tissue samples were kept at $-18^{\circ} \mathrm{C}$ until analysis. In the laboratory, the samples were dried at $105^{\circ} \mathrm{C}$ until dry mass was obtained. Then the bones were weighed (minimum $2 \mathrm{~g}$ ) and digested in concentrated nitric acid at $90^{\circ} \mathrm{C}$ for 10 hours. Before analysis, the samples were diluted to $25 \mathrm{ml}$ with distilled water. Detection limits were as follows: $\mathrm{Cd}=0.005 \mathrm{ppm}$, $\mathrm{Ni}=0.12 \mathrm{ppm}, \mathrm{Fe}=0.02 \mathrm{ppm}, \mathrm{Cu}=0.01 \mathrm{ppm}, \mathrm{Zn}=$ $0.13 \mathrm{ppm}$, and $\mathrm{Pb}=0.15 \mathrm{ppm}$. The recovery of the method was $96-98 \%$, and reproducibility was $>1.0 \%$. All metal concentrations were expressed on a dry-weight basis in $\mathrm{mg} \mathrm{kg}^{-1}$. From the final data, basic statistical characteristics were calculated (mean, SD, minimum, maximum, and median). Because the distribution of observed levels of heavy metals was normal according to Shapiro-Wilk test, parametric Student $t$ test was used for group comparisons employing the Statistica 7.0 software program.

For histological analysis, each right femur $(n=39)$ was sectioned at the midshaft of its diaphysis. In total, 39 transversal sections of the femur diaphysis were cut. The bone rings were washed in running water for 5 days to remove soft tissues in bone marrow. The bones were then defatted in a mixed solution of chloroform and methanol for 7 days and bleached in $2 \% \mathrm{H}_{2} \mathrm{O}_{2}$ solution for 1 day (Martiniaková et al. 2005). After dehydrating through graded alcohols (Martiniaková et al. 2006), the samples were embedded in epoxy resin (Biodur; Günter von Hagens, Germany). Transverse thin sections (70-80 $\mu \mathrm{m})$ were prepared with a sawing microtome (Leitz 1600, Germany), mounted on glass slides with Eukitt (Merck, Germany), and examined by light microscope (Jenaval, Germany) at $225 \times$. The qualitative histological characteristics of the compact bone microstructure were determined according to Enlow and Brown's (1956) and Ricqlés et al.'s (1991) classification systems; the quantitative ones were assessed using the computer software Scion Image (Scion, MD) in anterior, posterior, medial and lateral views of thin section(s). We measured area, perimeter, and the minimum and maximum diameter of primary osteons' vascular canals. The osteons were outlined using the software Scion Image on a microphotograph at a magnification of $225 \times$. The measured values $(n=135$ for $M$. glareolus and $n=95$ for $M$. arvalis) were expressed as mean \pm SD. Unpaired Student $t$ test was used to distinguish differences in the quantitative histological characteristics of compact bone between investigated voles. Correlations between 
heavy metals and bone structure were determined using the SPSS 8.0 statistical program (SPSS, Chicago, IL).

\section{Results}

Concentrations of selected heavy metals $(\mathrm{Pb}, \mathrm{Cd}, \mathrm{Fe}, \mathrm{Ni}$, $\mathrm{Cu}$, and $\mathrm{Zn}$ ) in the femora of $M$. glareolus from different types of polluted environments are listed in Table 1. Higher concentrations of $\mathrm{Pb}, \mathrm{Fe}, \mathrm{Cu}$, and $\mathrm{Zn}$ were detected in the bones of bank voles from Kolíňany. A significant difference was observed only for $\mathrm{Fe}(p<0.05)$. In contrast, concentrations of $\mathrm{Cd}$ and $\mathrm{Ni}$ were higher in the femora of individuals from the area of the power station in Nováky; however, these differences were not statistically significant.

Similarly, we observed higher concentrations of $\mathrm{Pb}, \mathrm{Fe}$, $\mathrm{Cu}$, and $\mathrm{Zn}$ in bones of $M$. arvalis from Kolínany (Table 2). Significant differences were detected for $\mathrm{Fe}$ and $\mathrm{Zn}$ $(p<0.05)$. Concentrations of $\mathrm{Cd}$ and $\mathrm{Ni}$ were also higher, although not significantly so, in individuals from the area of the power station in Nováky.

The measured values for bone weight and bone length were higher in bank and common voles from Nováky. The differences were statistically significant (Table 3).

Histological observation of thin sections of a shaft of femora from investigated voles showed an outer and inner nonvascular lamellar layer around a poorly developed reticular layer containing unorganized vascular canals (Figs. 2, 3). We rarely found several secondary osteons in femoral bone microstructure of bank and common voles, showing that the remodeling process of this rodent species is not as intensive compared with nonrodent mammals. In general, we did not identify demonstrable changes in qualitative histological characteristics of the femora in M. glareolus and M. arvalis (separately) from different biotopes.

With the quantitative histological characteristics, 135 vascular canals of primary osteons and 95 primary osteons' vascular canals were measured in bank and common voles,

Table 1 Concentrations of selected heavy metals in femora of M. glareolus from different polluted biotopes in Slovakia

\begin{tabular}{|c|c|c|c|c|c|c|c|}
\hline Locality & & $\mathrm{Pb}\left(\mathrm{mg} \mathrm{kg}^{-1}\right)$ & $\mathrm{Cd}\left(\mathrm{mg} \mathrm{kg}^{-1}\right)$ & $\mathrm{Ni}\left(\mathrm{mg} \mathrm{kg}^{-1}\right)$ & $\mathrm{Fe}\left(\mathrm{mg} \mathrm{kg}^{-1}\right)$ & $\mathrm{Cu}\left(\mathrm{mg} \mathrm{kg}^{-1}\right)$ & $\mathrm{Zn}\left(\mathrm{mg} \mathrm{kg}^{-1}\right)$ \\
\hline \multirow[t]{5}{*}{ Kolíňany } & $X$ & 20.46 & 4.01 & 9.52 & 212.99 & 4.16 & 188.55 \\
\hline & SD & 13.17 & 1.88 & 2.80 & 52.27 & 2.10 & 21.61 \\
\hline & Min & 9.26 & 1.08 & 6.75 & 140.58 & 1.87 & 154.68 \\
\hline & Max & 39.74 & 7.74 & 13.92 & 293.09 & 6.39 & 219.42 \\
\hline & Med & 18.87 & 3.13 & 8.46 & 172.53 & 4.04 & 151.46 \\
\hline \multirow[t]{5}{*}{ Nováky } & $X$ & 20.13 & 4.61 & 9.82 & $138.98 *$ & 3.78 & 176.07 \\
\hline & SD & 9.51 & 1.13 & 1.89 & 10.15 & 0.74 & 11.20 \\
\hline & Min & 14.08 & 3.71 & 7.93 & 128.19 & 3.20 & 164.21 \\
\hline & Max & 31.09 & 5.88 & 11.69 & 140.42 & 4.61 & 186.14 \\
\hline & Med & 19.84 & 3.76 & 8.17 & 138.17 & 3.81 & 174.14 \\
\hline
\end{tabular}

$X$ mean, min minimum, max maximum, med median

$* p<0.05$

Table 2 Concentrations of selected heavy metals in femora of $M$. arvalis from Kolínany and Nováky

\begin{tabular}{|c|c|c|c|c|c|c|c|}
\hline Locality & & $\mathrm{Pb}\left(\mathrm{mg} \mathrm{kg}^{-1}\right)$ & $\mathrm{Cd}\left(\mathrm{mg} \mathrm{kg}^{-1}\right)$ & $\mathrm{Ni}\left(\mathrm{mg} \mathrm{kg}^{-1}\right)$ & $\mathrm{Fe}\left(\mathrm{mg} \mathrm{kg}^{-1}\right)$ & $\mathrm{Cu}\left(\mathrm{mg} \mathrm{kg}^{-1}\right)$ & $\mathrm{Zn}\left(\mathrm{mg} \mathrm{kg}^{-1}\right)$ \\
\hline \multirow[t]{5}{*}{ Kolíňany } & $X$ & 20.41 & 2.76 & 6.84 & 159.27 & 3.31 & 138.52 \\
\hline & SD & 9.53 & 0.93 & 0.94 & 37.84 & 1.01 & 14.21 \\
\hline & Min & 13.58 & 1.98 & 6.37 & 103.63 & 2.24 & 104.56 \\
\hline & Max & 31.17 & 3.87 & 7.96 & 194.82 & 4.49 & 170.64 \\
\hline & Med & 21.19 & 3.04 & 7.05 & 168.42 & 3.42 & 144.98 \\
\hline \multirow[t]{5}{*}{ Nováky } & $X$ & 20.23 & 2.84 & 7.29 & $113.57^{*}$ & 3.05 & $129.45^{*}$ \\
\hline & SD & 8.98 & 1.11 & 1.14 & 26.85 & 0.87 & 10.12 \\
\hline & Min & 12.88 & 1.78 & 6.34 & 94.56 & 2.23 & 113.63 \\
\hline & Max & 29.34 & 4.05 & 8.69 & 144.23 & 4.66 & 147.37 \\
\hline & Med & 20.43 & 2.96 & 7.53 & 121.05 & 3.12 & 134.26 \\
\hline
\end{tabular}

$X$ mean, min minimum, $\max$ maximum, med median

$* p<0.05$ 
Table 3 Results of macroscopic analysis of investigated femora from bank and common voles

\begin{tabular}{llll}
\hline Animal & Locality & $\begin{array}{l}\text { Bone weight }(\mathrm{g}) \\
(\mathrm{X} \pm \mathrm{SD})\end{array}$ & $\begin{array}{l}\text { Bone length }(\mathrm{cm}) \\
(\mathrm{X} \pm \mathrm{SD})\end{array}$ \\
\hline M. glareolus & Kolíňany & $0.029 \pm 0.008$ & $1.297 \pm 0.109$ \\
& Nováky & $0.042 \pm 0.007^{*}$ & $1.637 \pm 0.088^{*}$ \\
M. arvalis & Kolíňany & $0.026 \pm 0.005$ & $1.261 \pm 0.093$ \\
& Nováky & $0.037 \pm 0.008^{*}$ & $1.512 \pm 0.071^{*}$
\end{tabular}

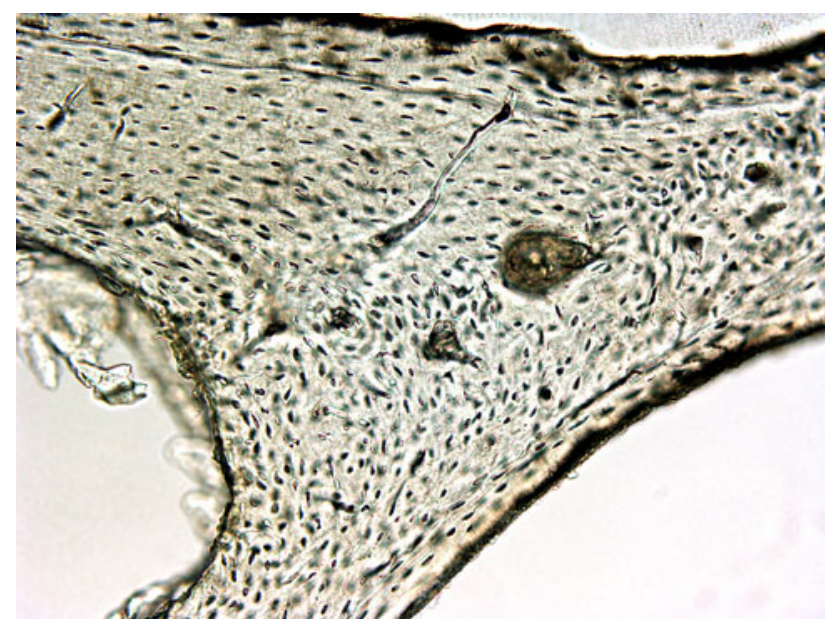

Fig. 2 Microphotograph of the femur in M. glareolus

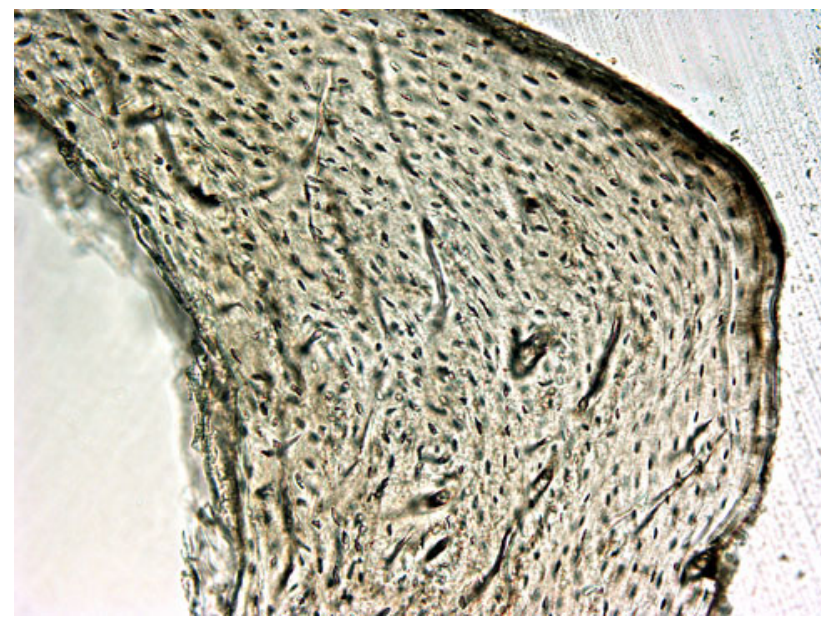

Fig. 3 Microphotograph of the femur in M. arvalis respectively. The results are listed in Table 4 . We found that all measured values for the vascular canals of primary osteons were higher in both species from Nováky. In contrast, no statistically significant differences were observed.

Correlation analysis in $M$. glareolus showed a strong positive relation between $\mathrm{Cd}$ and $\mathrm{Ni}(r=0.52), \mathrm{Pb}$ and bone weight $(r=0.53), \mathrm{Fe}$ and bone weight $(r=0.52)$, and $\mathrm{Fe}$ and size of the perimeter of primary osteons' vascular canals $(r=0.55)$. Results of correlation analysis are listed in Table 5. In common voles, a strong positive relation between $\mathrm{Fe}$ and $\mathrm{Cu}(r=0.60)$ and between $\mathrm{Fe}$ and perimeter size of vascular canals of primary osteons $(r=0.55)$ was found (Table 6).

\section{Discussion}

There is a significant relation between the amount of toxic elements in soil, water, food, and mammal organs, including bone. The results obtained by Jančová et al. (2006) suggest that concentrations of $\mathrm{Cu}, \mathrm{Fe}$, and $\mathrm{Cd}$ in selected organs (kidney, testis, and uterus) of yellownecked mouse (Apodemus flavicollis) from Nováky is significantly higher in all cases compared with those from Mochovce (a part relatively clean region in Nitra), respectively. It demonstrates an increase in pollution (mainly in the soil) due to the coal power station in Nováky resulting from mine work and/or from road traffic. According to Roberts and Johnson (1978) and Ieradi et al. (2003), one of the most important sources of environmental contamination from toxic elements is the coal industry. The dust emitted contains $\mathrm{Zn}, \mathrm{Cu}, \mathrm{Pb}$, and $\mathrm{Cd}$, and this contamination may increase the content of these elements in
Table 4 Measured values of vascular canals of primary osteons' variables in bank and common voles from Kolíňany and Nováky

$X$ mean

\begin{tabular}{llllll}
\hline Animal & Locality & $\begin{array}{l}\text { Area }\left(\mu \mathrm{m}^{2}\right) \\
(\mathrm{X} \pm \mathrm{SD})\end{array}$ & $\begin{array}{l}\text { Perimeter }(\mu \mathrm{m}) \\
(\mathrm{X} \pm \mathrm{SD})\end{array}$ & $\begin{array}{l}\text { Maximum diameter } \\
(\mu \mathrm{m})(\mathrm{X} \pm \mathrm{SD})\end{array}$ & $\begin{array}{l}\text { Minimum diameter } \\
(\mu \mathrm{m})(\mathrm{X} \pm \mathrm{SD})\end{array}$ \\
\hline M. glareolus & Kolíňany & $100.85 \pm 16.02$ & $27.95 \pm 4.27$ & $12.23 \pm 2.46$ & $4.67 \pm 0.69$ \\
& Nováky & $102.58 \pm 16.19$ & $28.76 \pm 3.97$ & $12.45 \pm 2.39$ & $4.71 \pm 0.74$ \\
M. arvalis & Kolíňany & $95.64 \pm 14.21$ & $25.12 \pm 3.56$ & $11.72 \pm 2.24$ & $4.26 \pm 0.58$ \\
& Nováky & $98.97 \pm 14.89$ & $27.36 \pm 3.78$ & $12.04 \pm 2.47$ & $4.83 \pm 0.69$
\end{tabular}


Table 5 Correlations between heavy metals and bone structure in M. glareolus

\begin{tabular}{|c|c|c|c|c|c|c|c|c|c|c|c|c|}
\hline & $\mathrm{Pb}$ & $\mathrm{Cd}$ & $\mathrm{Ni}$ & $\mathrm{Fe}$ & $\mathrm{Cu}$ & $\mathrm{Zn}$ & Weight & Length & Area & Peri & Max & Min \\
\hline $\mathrm{Pb}$ & 1 & 0.26 & 0.38 & 0.09 & 0.48 & 0.15 & 0.53* & 0.61 & 0.21 & 0.15 & 0.12 & 0.17 \\
\hline $\mathrm{Cd}$ & & 1 & 0.52 & 0.26 & 0.14 & 0.38 & -0.09 & -0.44 & 0.16 & 0.06 & -0.16 & 0.44 \\
\hline $\mathrm{Ni}$ & & & 1 & 0.34 & 0.42 & 0.31 & 0.39 & 0.36 & 0.35 & 0.19 & 0.25 & 0.32 \\
\hline $\mathrm{Fe}$ & & & & 1 & -0.08 & -0.26 & 0.52 & 0.17 & 0.50 & 0.55 & 0.58 & -0.09 \\
\hline $\mathrm{Cu}$ & & & & & 1 & -0.41 & 0.33 & 0.28 & 0.09 & -0.08 & 0.06 & -0.07 \\
\hline $\mathrm{Zn}$ & & & & & & 1 & -0.30 & -0.29 & 0.11 & -0.12 & -0.34 & 0.43 \\
\hline
\end{tabular}

Bolded numbers denoted a strong positive relation

Peri perimeter, $\max$ maximum diameter, $\min$ minimal diameter

$* p<0.05$

Table 6 Correlations between heavy metals and bone structure in M. arvalis

\begin{tabular}{|c|c|c|c|c|c|c|c|c|c|c|c|c|}
\hline & $\mathrm{Pb}$ & $\mathrm{Cd}$ & $\mathrm{Ni}$ & $\mathrm{Fe}$ & $\mathrm{Cu}$ & $\mathrm{Zn}$ & Weight & Length & Area & Peri & Max & Min \\
\hline $\mathrm{Pb}$ & 1 & 0.51 & -0.10 & 0.32 & 0.57 & -0.06 & 0.64 & 0.59 & 0.23 & 0.26 & 0.16 & 0.24 \\
\hline $\mathrm{Cd}$ & & 1 & 0.59 & -0.28 & 0.20 & 0.49 & 0.73 & 0.64 & 0.18 & 0.06 & -0.17 & 0.37 \\
\hline $\mathrm{Ni}$ & & & 1 & 0.63 & 0.44 & -0.70 & -0.47 & -0.36 & 0.29 & 0.32 & 0.34 & 0.31 \\
\hline $\mathrm{Fe}$ & & & & 1 & 0.60* & -0.67 & -0.12 & -0.08 & 0.51 & $\mathbf{0 . 5 5}^{*}$ & 0.48 & -0.07 \\
\hline $\mathrm{Cu}$ & & & & & 1 & -0.71 & 0.17 & 0.31 & 0.05 & -0.04 & 0.06 & -0.05 \\
\hline $\mathrm{Zn}$ & & & & & & 1 & 0.26 & 0.24 & 0.08 & -0.20 & -0.23 & 0.42 \\
\hline
\end{tabular}

Bolded numbers denoted a strong positive relation

$X$ mean, min minimum, max maximum, med median

$* p<0.05$

the tissues of mammals inhabiting polluted areas. In addition, it is known that concentrations of selected toxic elements (e.g., $\mathrm{Cd}, \mathrm{Pb}, \mathrm{Cu}$, and $\mathrm{Zn}$ ) in soft tissues and whole-body of $M$. glareolus are higher compared with Apodemus flavicollis (Sawicka-Kapusta et al. 1987; Metcheva et al. 2001). Therefore, we supposed that significantly higher concentrations of these elements would also be detected in the femora of M. glareolus from Nováky. Surprisingly, higher concentrations of $\mathrm{Pb}, \mathrm{Fe}, \mathrm{Cu}$, and $\mathrm{Zn}$ were detected in bones of bank voles from Kolínany, for which $\mathrm{Fe}$ concentration differences were significant. Similarly, we observed higher concentrations of $\mathrm{Pb}, \mathrm{Fe}, \mathrm{Cu}$, and $\mathrm{Zn}$ in the femora of common voles trapped at the same biotope, with both $\mathrm{Fe}$ and $\mathrm{Zn}$ differences being significant. These results can be explained by intensive agricultural production and subsequent contamination of soil, water, and food by road traffic pollution as well as by various factories in industrial zones in Nitra. Intensive agricultural production and the use of chemicals are characteristic for the whole region of Nitra. It is generally known that an application of agricultural chemicals can lead to a higher accumulation of specific elements, including $\mathrm{Fe}$ and $\mathrm{Zn}$, into the soil. In addition, there is heavy road traffic near the capture locality, which is also considered to be a significant source of heavy metals that have a potential ability to be transported by air flow over large distances. There is also a possibility of falling dust being transported in the air from large industrial regions, such as Bratislava, Vienna, Budapest, or factories near Nitra. This hypothesis may be supported by studies indicating the possibility of longrange transportation of heavy metals (Coggins et al. 2006).

Animals of both vole species trapped at Nováky had higher concentrations of $\mathrm{Cd}$ and $\mathrm{Ni}$ in their bones. However, the differences were not significant. Our results demonstrate a slightly increased accumulation of other heavy metals in the bones of M. glareolus and M. arvalis from Kolínany and thus provide evidence of environmental contamination.

We observed higher concentrations of $\mathrm{Cd}$ and $\mathrm{Zn}$ in the femora of M. glareolus (from both Nováky and Kolíñany) compared with the data reported by Milton et al. (2003). These investigators analyzed $\mathrm{Pb}\left(203 \pm 13.1 \mu \mathrm{g} \mathrm{g}^{-1}\right.$ dry weight), $\mathrm{Zn}\left(173 \pm 5.1 \mu \mathrm{g} \mathrm{g}^{-1}\right.$ dry weight $)$ and $\mathrm{Cd}(0.6 \pm$ $13.1 \mu \mathrm{g} \mathrm{g}^{-1}$ dry weight) concentrations in the femora of bank voles trapped at the contaminated, unused $\mathrm{Pb}$ mine at Frongoch in west Wales. Accordingly, the $\mathrm{Pb}$ concentration was lower in our study for both biotopes. In contrast, our values $(\mathrm{Pb}$ concentrations in the femora of bank voles from Kolíñany and Nováky) were higher than the reference value mentioned by Milton et al. (2003) (Pb concentration 
$3.2 \pm 0.8 \mu \mathrm{g} \mathrm{g}^{-1}$ dry weight). Concentrations of $\mathrm{Cd}$ and $\mathrm{Pb}$ were also higher in our study (from both Kolíñany and Nováky) compared with the value reported Milton and Johnson (1999). These investigators analyzed concentrations of $\mathrm{Pb}\left(0.99 \pm 0.14 \mu \mathrm{g} \mathrm{g}^{-1}\right.$ dry weight $), \mathrm{Zn}(261.1 \pm$ $7.4 \mu \mathrm{g} \mathrm{g}^{-1}$ dry weight), and $\mathrm{Cd}\left(0.15 \pm 0.04 \mu \mathrm{g} \mathrm{g}^{-1}\right.$ dry weight) in femora of laboratory-bred bank voles exposed to increased levels of dietary $\mathrm{Zn}$. The $\mathrm{Zn}$ concentrations in the femora of bank voles from Kolíňany and Nováky were lower in our study. In contrast, it was not possible to compare our results of heavy-metal concentration in the bones of $M$. arvalis with published data because of their absence in the literature.

We also found significant changes related to femoral length and weight between $M$. glareolus and $M$. arvalis from different types of polluted biotopes. The voles trapped at Nováky had higher values for both of these variables. Because all individuals were adult and of the same sex, and came from similar biotopes, we speculate this fact could indicate a growth-stimulating effect of some heavy metals. Some investigations based on the experimental exposures of individuals to risk elements have shown evidence of associations between body (bone) length and body (bone) weight and increased intake of $\mathrm{Pb}, \mathrm{Zn}$, or $\mathrm{Cd}$. According to Osweiler et al. (1985), $\mathrm{Pb}$ affects the metabolically active growth centers of long bones in young animals, having a positive effect on bone growth. Supplementation with $\mathrm{Zn}$ results in stimulation of skeletal growth and maturation (Moser-Veillon 1995). In addition, it has been demonstrated that long-term accumulation of $\mathrm{Cd}$ leads to decreased body weight and weight of some digestive organs in rats and rabbits (Toman et al. 1999, 2002). Our results could be explained by the above-noted findings only partially because femoral length and weight were higher in $M$. glareolus and $M$. arvalis with a higher concentration of $\mathrm{Cd}$ but not those of $\mathrm{Pb}$ and $\mathrm{Zn}$. However, it is known that low levels of the elements taken up from the natural environment may have a somewhat different effect on bone structure than exposure occurring under artificial conditions. These differences may be related to the differences in food quality and availability, the level of toxic elements in the ground, or differences in locomotive activity. According to the study by Velickovic (2007), black-striped mice (Apodemus agrarius, rodents) trapped at a contaminated site in Serbia had decreased body size and poorer body condition compared with mice caught in an unpolluted reference site. Decreased body size means that an individual also has decreased bone size. We observed lower values for bone length and weight in bank and common voles from Kolínany along with higher contents of $\mathrm{Pb}, \mathrm{Fe}$, $\mathrm{Cu}$, and $\mathrm{Zn}$ in the femora.

Our results from the qualitative histological analysis correspond with the data published by Enlow and Brown
(1958) and by Martiniaková et al. (2005) for compact bone microstructure of rodents. We rarely found several secondary osteons in our bone samples. It is generally known that aged rats and mice (rodents) lack true Haversian cortical bone remodeling but not cancellous bone remodeling activity (Erben 1996). Therefore, some secondary osteons can be observed in their long bones (near the endosteal border). The presence of several secondary osteons in our voles might also be related to biomechanics, body size, or phylogenetic origin of rodent species. In general, we did not identify demonstrable changes in qualitative histological characteristics between bank and common voles from different polluted biotopes. In addition, histomorphometry showed no statistically significant differences for measured variables of primary osteons' vascular canals between the animals. Therefore, we suppose that environmental factors (including heavy metals in the environment) influence the macroscopic structure of the bones in M. glareolus and $M$. arvalis trapped at different types of polluted environments in Slovakia. The voles from Nováky had significantly higher femoral length and weight compared with those from Kolínany in our study. In contrast, heavy metals did not affect compact bone morphology. According to Havill (2003), bone microstructural morphology is also genetically mediated and provides the direction for further exploration into this phenomenon. Beamer et al. (2001) mentioned that environmental factors are important contributors to variability in bone microstructure, but genetics still play a substantial role, and estimates of heritability range from 40 to $93 \%$.

It has been reported that essential and nonessential metals may interact with each other, thus affecting uptake, bioaccumulation and toxicity. The results of such interactions are highly variable and range from antagonism to synergism depending on the metal, its external concentration and exposure scenario, length of exposure, species, and specific organs (Norwood et al. 2003; Komjarova and Blust 2008). We observed a strong positive relation between $\mathrm{Cd}$ and $\mathrm{Ni}$ in the femora of bank voles. It is known that $\mathrm{Cd}$ as well as $\mathrm{Ni}$ and $\mathrm{Zn}$ interact actively with $\mathrm{Ca}$ channels (Paquin et al. 2002), which is typical for bone cells. According to Komjarova and Blust (2008), Cd, Ni, and $\mathrm{Zn}$ uptake rates are closely related to each other. A high correlation coefficient of 0.62 between $\mathrm{Ni}$ and $\mathrm{Cd}$ has also been observed in bones of people working in steel mills (Brodziak-Dopierala et al. 2009). In our study, a strong positive interaction between $\mathrm{Fe}$ and $\mathrm{Cu}$ in the femora of common voles was identified. $\mathrm{Cu}$ forms a synergetic system with $\mathrm{Fe}(\mathrm{Cu}-\mathrm{Fe})$, which advantageously influences the course of enzymatic processes. This interaction $(r=0.83)$ has been noted in trabecular bone of humans (Brodziak-Dopierala et al. 2009). In addition, research by Hisanaga et al. (1988) performed on bone samples taken 
from human ribs showed interactions between $\mathrm{Fe}$ and $\mathrm{Cu}$ that were characterized by a high correlation coefficient $(r=0.52)$. In both vole species, a strong positive relation between $\mathrm{Fe}$ and the perimeter size of primary osteons' vascular canals was found. This indicates that a higher content of $\mathrm{Fe}$ in bones significantly influences some variables of vascular canals of primary osteons in bank and common voles.

In conclusion, our contribution is a pilot study about the relation between femoral bone structure and accumulation of some heavy metals in the bones of bank and common voles from different types of polluted environments in Slovakia. Further research in this direction must extend the number of analyzed skeletal elements and verify the results that were obtained from our skeletal samples, especially in other species of small mammals.

Acknowledgments This study was supported by grant KEGA 3/ 7338/09 (Ministry of Education, Slovak Republic). The authors gratefully acknowledge revision of the English text by Kim Dammers (Konyang University).

Open Access This article is distributed under the terms of the Creative Commons Attribution Noncommercial License which permits any noncommercial use, distribution, and reproduction in any medium, provided the original author(s) and source are credited.

\section{References}

Angelova V, Ivanova R, Delibaltova V, Ivanov K (2004) Bioaccumulation and distribution of heavy metals in fiber crops (flax, cotton, and hemp). Ind Crops Prod 19:197-205

Appleton J, Lee KM, Sawicka-Kapusta K, Damek M, Cooke M (2000) The heavy metal content of the teeth of the bank vole (Clethrionomys glareolus) as an exposure marker of environmental pollution in Poland. Environ Pollut 110:441-449

Beamer WG, Shultz KL, Donahue LR, Churchill GA, Sen S, Wergedal JR et al (2001) Quantitative trait loci for femoral and lumbar vertebral bone mineral density in C57BL/6J and C3H/ HeJ inbred strains of mice. J Bone Miner Res 16:1195-1206

Brodziak-Dopierala B, Kwapulinski J, Kusz D, Gajda Z, Sobczyk K (2009) Interactions between concentrations of chemical elements in human femoral heads. Arch Environ Contam Toxicol 57: 203-210

Coggins AM, Jennings SG, Ebinghaus R (2006) Accumulation rates of the heavy metals lead, mercury and cadmium in ombrotrophic peatlands in the west of Ireland. Atmos Environ 40:260-278

Currey JD (2002) Bones: structure and mechanics. Princeton University Press, Princeton, NJ

de Ricqlés AJ, Meunier FJ, Castanet J, Francillon-Vieillot H (1991) Comparative microstructure of bone. In: Hall BK (ed) Bone 3: bone matrix and bone specific products, vol 1. CRC Press, Boca Raton, FL, pp 1-78

Enlow DH, Brown SO (1956) A comparative histological study of fossil and recent bone tissues. Part I Texas J Sci 8:405-412

Enlow DH, Brown SO (1958) A comparative histological study of fossil and recent bone tissues. Part III Texas J Sci 10:187-230

Erben RG (1996) Trabecular and endocortical bone surfaces in the rat: modeling or remodeling? Anat Rec 246:39-46
Friberg L, Nordberg GF, Vouk VB, Kessler E (1986) Handbook on the toxicology of metals. Elsevier, Amsterdam

Gdula-Argasinska J, Appleton J, Sawicka-Kapusta K, Spence B (2004) Further investigation of the heavy metal content of the teeth of the bank vole as an exposure indicator of environmental pollution in Poland. Environ Pollut 131:71-79

Gileva EA, Yalkovskaya LE, Polyavina OV, Boľshakov VN (2005) Common voles of the Microtus arvalis group in the Urals: genome instability and chromosomal polymorphism. Dokl Biol Sci 405:458-460

Goyer RA (1997) Toxic and essential metal interactions. Annu Rev Nutr 17:37-50

Haider S, Naithani V, Barthwal J, Kakkar P (2004) Heavy metal content in some therapeutically important medicinal plants. Bull Environ Contam Toxicol 72:119-127

Havill LM (2003) Osteon remodeling dynamics in Macaca mulatta: normal variation with regard to age, sex and skeletal maturity. Calcif Tissue Int 74:95-102

Hisanaga A, Hirata M, Tanaka A, Ishinishi N, Eguchi Y (1988) Variation of trace metals in ancient and contemporary Japanese bones. Biol Trace Elem Res 22:221-231

Ieradi LA, Zima J, Allegra F, Kotlánová E, Campanella L, Grossi R et al (2003) Evaluation of genotoxic damage in wild rodents from a polluted area in the Czech Republic. Folia Zool 52:57-66

Jančová A, Massányi $\mathrm{P}$, Nad̆ $\mathrm{P}$, Koréneková B, Skalická M, Drábeková $J$ et al (2006) Accumulation of heavy metals in selected organs of yellow necked mouse (Apodemus flavicollis). Ekol Bratislava 25:19-26

Kido T, Nogawa K, Hochi Y, Hayano M, Honda R, Tsuritani I et al (1993) The renal handling of calcium and phosphorus in environmental cadmium-exposed subjects with renal dysfunction. J Appl Toxicol 13:43-47

Komjarova I, Blust R (2008) Multi-metal interactions between Cd, $\mathrm{Cu}, \mathrm{Ni}, \mathrm{Pb}$ and $\mathrm{Zn}$ in water flea Daphnia magna: a stable isotope experiment. Aquat Toxicol 90:138-144

Leung PL, Huang HM, Sun DZ, Zhu MG (1999) Hair concentrations of calcium, iron, and zinc in pregnant women and effects of supplementation. Biol Trace Elem Res 69:269-282

Macdonald DW, Tattersall FH (2001) Britain's mammals: the challenge for conservation. People's Trust for Endangered Species, London, UK

Martiniaková M, Grosskopf B, Vondráková M, Omelka R, Fabiš M (2005) Observation of the microstructure of rat cortical bone tissue. Scripta Medica 78:45-50

Martiniaková M, Grosskopf B, Omelka R, Vondráková M, Bauerová M (2006) Differences among species in compact bone tissue microstructure of mammalian skeleton: use of a discriminant function analysis for species identification. J Forens Sci 51:1235-1239

Martiniaková M, Grosskopf B, Omelka R, Dammers K, Vondráková M, Bauerová M (2007) Histological study of compact bone tissue in some mammals: a method for species determination. Int J Osteoarch 17:82-90

Metcheva R, Teodorova S, Topashka-Ancheva M (2001) A comparative analysis of the heavy metals and toxic elements loading indicated by small mammals in different Bulgarian regions. Acta Zool Bulg 53:61-80

Milton A, Johnson M (1999) Biomonitoring of contaminated mine tailings through age accumulation of trace metals in the bank vole (Clethrionomys glareolus). J Environ Monit 1:219-225

Milton A, Cooke JA, Johnson MS (2003) Accumulation of lead, zinc, and cadmium in a wild population of Clethrionomys glareolus from an abandoned lead mine. Arch Environ Contam Toxicol 44:405-411

Moser-Veillon RB (1995) Zinc needs and homeostasis during lactation. Analyst 120:895-897 
Moska M, Kosowska B, Brzezinska K (2004) Karyotype of the common vole (Microtus arvalis) from the Sowie mountains. EJPAU 7:\#08

Norwood WP, Borgmann U, Dixon DG, Wallace A (2003) Effects of metal mixtures on aquatic biota: a review of observations and methods. Hum Ecol Risk Assess 9:795-811

Osweiler GD, Carson TL, Buck WB, Van Gelder GA (1985) Clinical and diagnostic veterinary toxicology. Kendall/Hunt Publishing Company, Dubuque, IA

Paquin PR, Gorsuch JW, Apte S, Batley GE, Bowles KS, Campbell PGC et al (2002) The biotic ligand model: a historical overview. Comp Biochem Physiol C 133:3-35

Rho JZ, Kukn-Spearing L, Zioupos P (1998) Mechanical properties and the hierarchical structure of bone. Med Eng Phys 20:92-102

Roberts RD, Johnson MS (1978) Dispersal of heavy metals from abandoned mine transference through terrestrial food chains. Environ Pollut 16:293-310

Sawicka-Kapusta K, Górecki A, Lange R (1987) Heavy metals in rodents from polluted forests in southern Poland. Ekologia Polska 35:345-354

Shore RF (1995) Predicting cadmium, lead and fluoride levels in small mammals from soil residues and by species-species extrapolations. Environ Pollut 88:333-340

Shore RF, Rattner BA (2001) Ecotoxicology of wild mammals. Wiley, London

Stawarz R, Zakrzewski M, Marenčík A, Hraška Š (2003) Heavy metal concentration in the toad Bufo Bufo from a region of Mochovce, Slovakia. Ekol Bratislava 22:292-297
Toman R, Massányi P, Kováčik J (1999) Growth and reproductive ability of male rabbits after cadmium intake from diet. Folia Vet 43:182-185

Toman R, Massányi P, Čupka P, Lukáč N, Ducsay L, Kolenkáš M, et al. (2002) Changes in weight of some organs and weight of rats under the influence of cadmium receiving in the diet from wean to sexual maturity [in Slovak]. In: Risk factors of the food chain: proceeding book, pp 154-157. Nitra, Slovakia

Topashka-Ancheva M, Metcheva R, Teodorova S (2003) A comparative analysis of the heavy metal loading of small mammals in different regions of Bulgaria II: chromosomal aberrations and blood pathology. Ecotoxicol Environ Saf 54:188-193

Topolska K, Sawicka-Kapusta K, Cieslik E (2004) The effect of contamination of the Krakow region on heavy metals content in the organs of bank voles (Cleithrionomys glareolus, Schreber, 1780). Pol J Environ Stud 13:103-109

Velickovic M (2007) Measures of the developmental stability, body size and body condition in the black-striped mouse (Apodemus agrarius) as indicators of a disturbed environment in northern Serbia. Belg J Zool 137:147-156

Wijnhoven S, Leuven RSEW, van der Velde G, Eijsackers HJP (2008) Toxicological risk for small mammals in a diffusely and moderately polluted floodplain. Sci Total Environ 406:401-406

Zemanek M (1972) Food and feeding habits of rodents in a deciduous forest. Acta Theriol 23:315-325 